\title{
FATWA MUI TENTANG VASEKTOMI Tanggapan Ulama dan Dampaknya terhadap Peningkatan Medis Operasi Pria (MOP)
}

\author{
Muhyiddin \\ IAIN Walisongo Semarang \\ e-mail: muhyiddin@walisongo.ac.id
}

\begin{abstract}
This field research aims to determine three things: the background of the changing legal opinion (fatwa) of MUI on Vasectomy from 'haram' to 'halal on condition'; responses from the Moslem scholars; and the impact of fatwa on increasing the number of Vasectomy participants in Central Java. The data collection was done by using documentation and interviews while data analysis was done by using descriptive qualitative method. The results of this research are: 1) The reason for the changing fatwa on Vasectomy from 'haram' to 'halal on condition' is due to a new 'illat, namely the success of recanalization. 2) Against the new fatwa, Ulama Muhammadiyah approved it by tightening and adding certain requirements. While Ulama NU disagree on the fatwa as evidence of the success of recanalization is considered not convincing (muhaqqaqah). 3) The new fatwa has not been an impact on increasing the number of Vasectomy participants in Central Java.
\end{abstract}

[]

Penelitian ini merupakan penelitian lapangan yang bertujuan untuk mengetahui tiga hal, yaitu: latar belakang perubahan fatwa MUI tentang vasektomi dari haram menjadi halal dengan syarat; tanggapan ulama; dan pengaruh fatwa terhadap peningkatan jumlah peserta vasektomi di Jawa Tengah. Pengumpulan data dilakukan dengan teknik dokumentasi dan wawancara sedangkan analisis data dilakukan dengan teknik deskriptif kualitatif. Hasil penelitian ini adalah: 1) Alasan perubahan fatwa hukum vasektomi dari haram menjadi halal dengan syarat adalah karena adanya illat baru, yaitu keberhasilan rekanalisasi. 2) Terhadap fatwa baru tersebut, Ulama Muhammadiyah menyetujui dengan pengetatan dan penambahan syarat tertentu. Sedangkan ulama NU kurang setuju terhadap fatwa tersebut karena bukti keberhasilan rekanalisasi dianggap belum meyakinkan (muhaqqaqah). 3) Fatwa baru vasektomi tersebut belum berdampak pada peningkatan jumlah peserta vasektomi di Jawa Tengah.

Keywords: fatwa, Majelis Ulama Indonesia, vasektomi

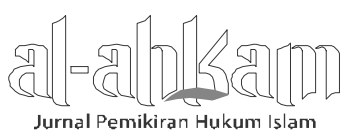


Muhyiddin

\section{Pendahuluan}

MUI sejak awal kelahirannya 26 Juli 1975 identik dengan lembaga fatwa, artinya lembaga yang aktivitas dan produknya lebih banyak atau lebih dominan memberikan fatwa-fatwa agama untuk persoalan keumatan dan keindonesiaan, dibanding kegiatan yang lain. Sampai dengan saat ini, MUI sudah menerbitkan ratusan fatwa berbagai bidang; bidang akidah dan aliran kepercayaan, bidang ibadah, bidang sosial dan budaya, bidang pangan, obat-obatan, iptek, dan bidangbidang lain. Khusus dalam forum ijtimā' ulama yang diselenggarakan setiap tiga tahun sekali (sampai dengan tahun 2012 sudah empat kali pelaksanaan; 2003, 2006, 2009, dan 2012) selalu dikaji tiga bidang pokok yaitu; masā'il asāsiyyah wațāniyyah (masalah-masalah strategis kebangsaan), masā'il fiqhiyyah mu'așirah (masalah-masalah fikih kotemporer), dan masāill qānūniyyah (masalah hukum dan perundang-undangan).

Cukup menarik untuk dicermati, yaitu fatwa keharaman vasektomi yang biasa disebut Medis Operasi Pria (MOP) yang merupakan salah satu kontrasepsi KB pria dan tergolong kontrasepsi mantap atau KONTAP. Vasektomi merupakan tindakan penutupan (pemotongan, pengikatan, penyumbatan) kedua saluran sperma sebelah kanan dan kiri, sehingga pada waktu ejakulasi cairan mani yang keluar tidak lagi mengandung sperma, sehingga tidak terjadi kehamilan. ${ }^{1}$ Tindakan ini lebih ringan dari sunat atau khitan, pada umumnya dilakukan sekitar 10-15 menit, dengan cara memotong dan mengikat saluran sperma (vas deferens) yang terdapat di dalam kantong buah zakar.

Menurut KH. Afifuddin Muhajir, vasektomi ialah tindakan memotong dan mengikat saluran spermatozoa dengan tujuan menghentikan aliran spermatozoa, sehingga air mani tidak mengandung spermatozoa pada saat ejakulasi tanpa mengurangi volume air mani. Atau usaha mengikat atau memotong saluran benih pria (vas deferens) sehingga pria itu tidak dapat menghamilkan. Apabila hal yang sama dilakukan terhadap wanita, dinamakan tubektomi, ialah usaha mengikat atau memotong kedua saluran telur, sehingga wanita itu pada umumnya tidak dapat hamil kembali. ${ }^{2}$

\footnotetext{
${ }^{1}$ Badan Kependudukan dan Keluarga Berencana, Informasi Pelayanan Kategori Mantap Pria (Vasektomi) (Jakarta: Badan Kependudukan dan Keluarga Berencana, 2011), h. 11.

2Majelis Ulama Indonesia, Himpunan Fatwa Majelis Ulama Indonesia (Jakarta: Ditjen BIPH Departemen Agama RI, 2010), h. 299.
} 
Menariknya persoalan hukum vasektomi, karena selama kurun waktu lebih kurang 30 tahun (1979 sampai dengan 2012) ditetapkan hukumnya dalam bentuk fatwa MUI sebanyak empat kali; tiga kali fatwa dinyatakan haram dan yang terakhir dinyatakan haram kecuali keadaan memenuhi syarat. Yang terakhir inilah menegaskan kebolehan (ibāḥah) vasektomi dengan syarat.

Pertama, di tahun 1979, di mana merupakan masa-masa awal gencarnya program Keluarga Berencana, MUI memfatwakan keharaman vasektomi dengan dua alasan pokok, yaitu 1) vasektomi merupakan bentuk usaha pemandulan, sedangkan pemandulan dilarang oleh Islam; 2) di Indonesia belum dapat dibuktikan bahwa vasektomi dapat disambung kembali. ${ }^{3}$ Kedua, pada tahun 1983, pada forum Musyawarah Nasional tentang kependudukan, kesehatan dan pembangunan, tanggal 17-30 Oktober 1983, MUI kembali menegaskan keharaman vasektomi dan tubektomi menguatkan fatwa tahun 1979. Dalam keputusannya, hanya karena alasan darurat vasektomi dan tubektomi bisa dibolehkan seperti terancamnya jiwa si janin apabila mengandung atau melahirkan. ${ }^{4}$ Ketiga, pada bulan Januari 2009 dilaksanakan forum ijtimā' ulama komisi fatwa MUI ketiga di Padang Panjang Sumatera Barat. Menjelang pelaksanaan forum tersebut, Pemerintah cq Departemen Kesehatan RI dan BKKBN berusaha mendekati dan memohon agar MUI merevisi hukum vasektomi dari haram menjadi mubah atau tidak haram. Hal itu dilakukan Pemerintah mengingat pentingnya vasektomi sebagai salah satu metode $\mathrm{KB}$ pria yang paling efektif dan minim resiko dibanding metode $\mathrm{KB}$ wanita atau kontrasepsi lain. ${ }^{5}$ Angka kesertaan $\mathrm{KB}$ pria khususnya vasektomi sangat rendah, di bawah 0,2\% dibanding metode KB yang lain. Sementara, Pemerintah menganggap salah satu hambatan program KB pria vasektomi adalah fatwa haram MUI. Maka dibangun atau disusunlah argumentasi bahwa vasektomi memungkinkan direkanalisasi, sehingga alasan hukum haram berupa pemandulan permanen tereliminasi atau terbantah. Tetapi argumentasi tersebut dianggap tidak cukup kuat karena kurang atau tidak adanya bukti, sehingga ulama tetap memandang vasektomi sebagai usaha pemandulan. Maka lahirlah keputusan fatwa ketiga kalinya dengan hukum haram pada tanggal 26 Januari $2009 .^{6}$

\footnotetext{
3Ibid., h. 331.

4Ibid., h. 299.

5Penjelasan Erna Sulistiyowati, Kepala Bidang KB-KR Kementerian Kesehatan, tanggal 21 Maret 2013.

${ }^{6}$ Majelis Ulama Indonesia, Keputusan Ijtima' Ulama Komisi Fatwa se-Indonesia III (Jakarta: MUI, 2009), h. 61.

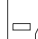

Jurnal Pemikiran Hukum Islam 
Muhyiddin

Keempat, menjelang diselenggarakannya forum ijtimā' ulama keempat, Juni/Juli 2012 di Cipasung Tasikmalaya, Pemerintah kembali mengajukan dan menguatkan argumentasi berkaitan dengan bukti keberhasilan rekanalisasi (Surat Kementerian Kesehatan Republik Indonesia, No. TU.05.02/V/1016/ 2012, tanggal 11 Juni 2012, tentang Permohonan Peninjauan Vasektomi). Ada dua bukti penguat yang diajukan:

1. Pemerintah (BKKBN Provinsi Jawa Tengah) dengan menggandeng MUI Provinsi Jawa Tengah dan MUI Kabupaten Situbondo (Jawa Timur) menemukan bukti nyata bahwa rekanalisasi benar-benar berhasil, yaitu pernyataan dan testimoni Mbah Poleng (Njoto Djatmiko), asal Surabaya dengan istri keduanya melahirkan dua orang anak perempuan dan laki-laki, setelah lebih kurang satu tahun direkanalisasi. Sebelumnya dia telah melakukan vasektomi beberapa tahun dengan istri pertama yang kemudian meninggal (melaksanakan vasektomi September 1988, melakukan rekanalisasi 13 Juli 1999, anak pertama perempuan lahir 17 Juni 2000, anak kedua laki-laki lahir 8 Desember 2006). Bukti berupa pernyataan dan testimoni yang bersangkutan terlampir.

2. Kecuali bukti tersebut huruf a, juga dikuatkan dengan bukti pernyataan Perhimpunan Dokter Spesialis Urologi Indonesia (IAUI), tanggal 9 Juni 2012, dilaksanakan di Hotel Aston Bogor, bahwa rekanalisasi secara medis profesional bisa berhasil.

Maka melalui kajian bukti baru tersebut yang dianggap sebagai 'illat hukum vasektomi, ijtimā' ulama menetapkan fatwa vasektomi "haram kecuali...." atau "mubah dengan syarat....". Pasca lahirnya fatwa dari ijtimā' ulama keempat, Juli 2012 dan berjalan selama lebih kurang satu tahun, penulis ingin mengetahui secara detail melalui penelitian akademik guna mendapatkan gambaran yang sebenarnya. Maka dilakukan penelitian dengan judul "Fatwa MUI tentang Vasektomi (Tanggapan Ulama dan Dampaknya terhadap Peningkatan MOP)"

Penelitian ini bertujuan untuk; pertama, memahami latar belakang lahirnya fatwa MUI tentang vasektomi. Kedua, mengetahui tanggapan ulama terhadap fatwa tersebut. Ketiga, mengetahui seberapa besar (ada atau tidak) dampak fatwa tesebut terhadap meningkatnya jumlah vasektomi di Jawa Tengah.

\section{Fatwa Ulama}

Fatwa merupakan salah satu substansi pemikiran hukum dari ulama terutama di negeri-negeri yang penduduknya mayoritas Muslim, termasuk di Indonesia. Menurut Atho' Mudzhar, produk pemikiran Hukum Islam dari para ahli Hukum

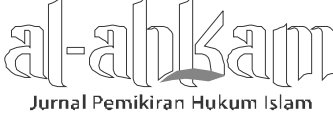


Islam dapat dilihat pada 5 (lima) hal, yaitu kitab-kitab fikih, putusan pengadilan agama, perundang-undangan yang berlaku di negeri Muslim, kompilasi Hukum Islam, dan fatwa. ${ }^{7}$ Cik Hasan Bisri menyatakan bahwa aspek statis wilayah penelitian Hukum Islam meliputi: 1) dimensi syariah, 2) dimensi fikih, 3) dimensi fatwa, 4) dimensi qānūn, 5) dimensi nizām, 6) dimensi idārah, 7) dimensi qaḍā' dan 8) dimensi adat.8 Atho Mudzhar dan Cik Hasan Bisri sama-sama menyebut "fatwa" sebagai sasaran kajian atau penelitian.

Studi dan penelitian Hukum Islam yang hidup di suatu negeri bisa melihat pada kitab-kitab/buku-buku fikih yang ditulis oleh ulama negeri tersebut, bisa dilakukan terhadap yurisprudensi (putusan) peradilan yang ada di lingkungan negeri itu, bisa ditujukan pada peraturan perundang-undangan yang berlaku yang ditetapkan oleh lembaga legislatifnya, bisa dengan mempelajari kompilasi Hukum Islam seperti Kompilasi Hukum Islam di Indonesia yang diangkat dengan kekuatan hukum Inpres No. 1 Tahun 1991, dan bisa terhadap fatwa ulamanya. Sedangkan studi fatwa-fatwa ulama di Indonesia bisa dilakukan terhadap fatwa Komisi Fatwa MUI, fatwa Majelis Tarjih Muhammadiyah, fatwa Baḥth al-Masā'il al-Dinniyyah NU atau fatwa dari lembaga lain.

Studi terhadap fikih, yurisprudensi (putusan) peradilan agama dan peraturan perundang-undangan sudah relatif lebih banyak daripada studi terhadap fatwa. Oleh karena itu, studi fatwa MUI yang dilakukan Atho' Mudzhar merupakan studi rintisan yang berguna menjadi rujukan studi fatwa berikutnya, sebagaimana dinyatakan sendiri oleh Atho' Mudzhar. ${ }^{9}$

Studi Hukum Islam terhadap kitab-kitab fikih klasik bisa berupa studi pemikiran fikih klasik, yang mungkin tidak hidup lagi di suatu negeri, dan bisa berupa pemikiran modern yang masih aktual. Tetapi, studi terhadap fatwa ulama di Indonesia lebih banyak menuju terhadap fikih yang hidup di Indonesia sesuai de-

7M. Atho' Mudzhar, Pendekatan Studi Islam dalam Teori dan Praktek (Yogyakarta: Pustaka Pelajar, 2002), h. 245.

${ }^{8}$ Cik Hasan Bisri, Pilar-pilar Penelitian Hukum Islam dan Pranata Sosial (Jakarta: RajaGrafindo Persada, 2004), h. 78-121.

'Mohammad Atho' Mudzhar, Fatwa-fatwa Majelis Ulama Indonesia: Sebuah Studi tentang Pemikiran Hukum Islam di Indonesia Tahun 1975-1988 (Jakarta: INIS, 1993), h. 6. Studi fatwa berikutnya dilakukan oleh Dede Rosyada tahun 1999 dengan judul "Metode Kajian Hukum Dewan Hisbah PERSIS", dan dilakukan oleh Rifyal Ka'bah tahun 1999 dengan judul "Hukum Islam di Indonesia: Perspektif Muhammadiyah dan NU."

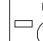

Jurnal Pemikiran Hukum Islam 
Muhyiddin

ngan persoalan yang ada, karena fatwa adalah putusan hukum yang menjawab persoalan praktis dan aktual.

Berkait dengan fatwa sebagai salah satu bentuk fikih praktis di Indonesia ini, akan diuraikan tentang pengertian fatwa, kebutuhan umat Islam pada fatwa dan lembaga-lembaga fatwa di Indonesia.

\section{Pengertian Fatwa}

Secara bahasa fatwa adalah kata dalam bahasa Arab "al-fatwa" yang sudah meresap ke dalam bahasa Indonesia "fatwa", artinya jawaban pertanyaan hukum, atau petuah. ${ }^{10}$ Sedangkan secara istilah, menurut Amir Syarifuddin, fatwa adalah usaha memberikan penjelasan tentang hukum Syara' oleh ahlinya kepada orang yang belum mengetahuinya. ${ }^{11}$

Aktivitas penetapan fatwa oleh seorang mufti atau lembaga fatwa lebih tepat disebut dengan istilah "iftā", artinya penetapan fatwa. Orang atau lembaga yang memiliki otoritas menetapkannya disebut " $m u f t$ ", orang atau pihak yang meminta fatwa disebut "mustafti", sedangkan jawaban hukum sebagai produknya disebut "mustafta fih" atau "fatwā". Keempat hal (iftā', muftī, mustaftī dan fatwā) tersebut oleh ulama ahli uşūl disebut rukun fatwa. ${ }^{12}$

Dengan statusnya sebagai rukun, maka itu artinya sesuatu yang mesti ada, bahwa adanya fatwa hukum sebagai produk disebabkan adanya persoalan hukum yang dipertanyakan oleh mustaftī, yang berarti pula menunjukkan adanya aktivitas iftā', yaitu pengkajian dan pembahasan hukum sampai ijtihad hukum. Maka pelakunya, mufti harus memiliki kemampuan berijtihad atau istinbāț hukum.

\footnotetext{
10Mahmud Yunus, Kamus Arab-Indonesia (Jakarta: Yayasan Penyelenggara Penerjemah/ Pentafsir al-Qur'an, 1973), h. 308. Bandingkan dengan Muhammad Idrīs Abd al-Raūf al-Marbawi, Qāmūs al-Marbawi, Juz II (Singapura: Pustaka Nasional, 1354 H), h. 78. Bandingkan juga dengan Ajip Rosjidi (ed.), Ensiklopedi Indonesia 2 (Jakarta: Ichtiar Baru Van Hoeve, 1991), h. 994.

${ }^{11}$ Amir Syarifuddin, Ushul Fiqh, jilid 2 (Jakarta: Logos Wacana Ilmu, 1999), h. 429. Tidak jauh dengan ta'rif tersebut, dalam Ensiklopedi Hukum Islam dijelaskan bahwa fatwa berarti pendapat yang dikemukakan seorang mujtahid atau faqih sebagai jawaban yang diajukan peminta fatwa dalam suatu kasus yang sifatnya tidak mengikat. Abdul Aziz Dahlan dan Satria Effendi M. Zein (ed.), Ensiklopedi Hukum Islam, Jilid 1 (Jakarta: Ichtiar Baru Van Houve, 1997), h. 326.
}

${ }^{12}$ Amir Syarifuddin, Ushul Fiqh, h. 429. Tidak jauh dengan ta'rifftersebut, dalam Ensiklopedi Hukum Islam dijelaskan bahwa fatwa berarti pendapat yang dikemukakan seorang mujtahid atau faqih sebagai jawaban yang diajukan peminta fatwa dalam suatu kasus yang sifatnya tidak mengikat. Abdul, Ensiklopedi, h. 429-430.

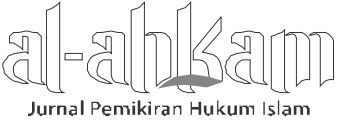


Atas dasar pengertian dan uraian di atas, maka fatwa sebagai salah satu model fikih, yaitu merupakan pandangan ulama mengenai persoalan keagamaan (hukum) yang bersifat praktis dan aktual. Umat Islam pada dasarnya boleh tidak terikat dengan isi fatwa itu sebagaimana tidak terikat dengan salah satu fikih mazhab, tetapi secara moral dan sosial wajib menjadikan fatwa sebagai pegangan/ pedoman, karena fatwa itu diterbitkan untuk dijadikan pegangan/pedoman umat dalam kehidupan beragama dan bermasyarakat.

\section{Kebutuhan Umat pada Fatwa}

Manusia apabila dihubungkan dengan kemampuan/kesanggupannya memahami hukum syara' yang diturunkan Allah SWT dan Rasulullah SAW berupa ayat al-Qur'an dan Sunnah Rasul terbagi menjadi dua kelompok. Pertama, kelompok orang-orang yang memiliki kesanggupan ijtihad. Merekalah yang disebut mujtahidīn. Kedua, kelompok orang-orang yang tidak memiliki kesanggupan ijtihad, yang merupakan kelompok terbesar. Mereka itulah yang disebut orang awam. ${ }^{13}$

Bagi orang awam, karena keterbatasan kemampuannya, untuk beberapa persoalan agama, wajib bertanya kepada orang yang ahli, sesuai dengan perintah al-Qur'an sebagai berikut:

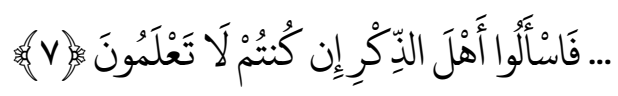

“... maka tanyakanlah olehmu kepada orang-orang yang berilmu, jika kamu tidak mengetahui."14

Perintah bertanya kepada orang ahli yang bersifat umum ini mencakup perintah meminta fatwa kepada muftī/fuqahā'. Al-Ghazāli menegaskan:

$$
\text { العامى يجب عليه الإستفتاء واتباع العلماء15 }
$$

"Orang awam wajib meminta fatwa (kepada mufti) dan mengikuti pendapat ulama."

\footnotetext{
${ }^{13}$ Mukhtar Yahya dan Fatchurrahman, Dasar-dasar Pembinaan Hukum Fikih Islam (Bandung: alMa'arif, 1986), h. 403. Bandingkan dengan Badrān Abū al-'Aynayn, Ușül al-Fiqh al-Islāmī (Iskandariyah: Mu'assasah Syabāb al-Jāmi'ah, 1984), h. 494.

${ }^{14}$ QS. al-Anbiyā: 7.

${ }^{15}$ Abū Ḥāmid Muhammad ibn Muhammad al-Ghazālī, al- Mustasfã min IIm al-Ușūl, jilid 2 (t.tp: Dār al-Fikr, t.th.), h. 389.
} 
Muhyiddin

Kalau sasaran perintah itu ditujukan kepada orang kebanyakan (awam) berarti begitu banyaknya kebutuhan fatwa atau kebutuhan akan jawaban hukum, dan begitu pentingnya keberadaan mufti atau lembaga pemberi fatwa. Itulah argumentasi awal/dasar kita melihat adanya kebutuhan umat pada fatwa.

Kenyataan menunjukkan adanya kebutuhan itu berupa banyaknya pertanyaan/permintaan masyarakat tentang berbagai persoalan hukum yang menuntut jawaban hukum. Ini dibuktikan oleh hasil penelitian Atho' Mudzhar yang menyatakan bahwa fatwa itu dikeluarkan sebagai tanggapan atas keprihatinan umum pada suatu waktu atau atas pertanyaan Pemerintah atau badan-badan lain, dan sebagaian atas pertanyaan orang-orang Islam secara perseorangan. ${ }^{16}$ Pertanyaan dan persoalan hukum itu menjadi semakin meningkat baik kuantitas maupun (apalagi) kualitas, sehubungan dengan kompleksitas masalah dalam kehidupan masa kini yang muncul sebagai dampak berkembangnya ilmu pengetahuan dan teknologi modern.

\section{Lembaga Fatwa di Indonesia}

Mufti sebagai pihak yang memiliki otoritas fatwa keagamaan itu bisa perseorangan dan bisa berbentuk lembaga. Apabila mufti itu berupa perorangan, maka banyak mufti perorangan di Indonesia dalam perjalanan sejarah yang menjadi tempat rujukan dan pertanyaan umat, baik fatwa itu dilakukan secara lisan yang kemudian tidak terdokumentasi, maupun dilakukan secara tertulis dan terdokumentasi dalam sebuah buku, misalnya fatwa oleh A. Hasan, KH. Sirojuddin Abbas, KH. Mustofa Bisri.

Tetapi apabila dimaksudkan dengan muftī (pemberi fatwa) itu dalam bentuk lembaga, maka lembaga pemberi fatwa di Indonesia yang mengemuka (dikenal banyak orang) adalah Majelis Tarjih Muhammadiyah, Baḥth al-Masā'il al-Dīniyyah NU dan Komisi Fatwa MUI. Sebenarnya masih ada lembaga fatwa lain yang belum tersosialisasi dengan baik seperti lembaga fatwa di bawah "Hizbut Tahrir Indonesia" dan Dewan Hisbah Persis. Yang disebut terakhir produk fatwanya telah

\footnotetext{
16M. Atho', Pendekatan, h. 255. Bandingkan dengan Ensiklopedi Hukum Islam 3, yang menjelaskan bahwa pertimbangan yang menjadi dasar bagi Komisi Fatwa MUI untuk membahas suatu masalah adalah adanya permintaan dari pihak Pemerintah, atau adanya permintaan organisasi, kelompok atau perorangan, atau adanya suatu kasus yang perlu diselesaikan oleh MUI dengan mengeluarkan fatwa. Abdul, Ensiklopedi ..., h. 984.
} 
diteliti oleh Dede Rosyada dalam sebuah buku "Metode Kajian Hukum Dewan Hisbah PERSIS".17

\section{Vasektomi}

Program KB secara nyata sudah berhasil memberikan sumbangan pada pemenuhan hak-hak reproduksi dan kesejahteraan keluarga. Pendekatan program KB saat ini tidak hanya fokus pada program pengendalian populasi dan penurunan fertilitas tetapi juga diarahkan pada pemenuhan hak-hak reproduksi dan kesetaraan gender. Walaupun pemerintah telah mulai melaksanakan pembangunan yang berorientasi pada kesetaraan dan keadilan gender, namun pelayanan $\mathrm{KB}$ saat ini masih terkesan bias gender atau lebih banyak terfokus kepada perempuan. Kondisi tersebut mengakibatkan proses dan kualitas penyampaian komunikasi, informasi, dam edukasi (KIE) masih belum seimbang, termasuk dalam hal sarana pelayanan dan penyediaan alat kontrasepsi pria.

Menurut data SDKI 2007, kesetaraan pria dalam Keluarga Berencana dan KR hingga saat ini masih sangat rendah yaitu hanya 1,5\% meliputi penggunaan kondom 1,3\% dan vasektomi 0,2\%. Beberapa peneliti menujukkan bahwa rendahnya kesertaan pria dalam KB disebabkan oleh beberapa faktor diantaranya: 1) Akses informasi yang terbatas; 2) Akses pelayanan yang terbatas; 3) Akses dukungan sosial budaya termasuk dukungan dari tokoh agama dan tokoh masyarakat. ${ }^{18}$

Vasektomi merupakan tindakan penutupan (pemotongan, pengikatan, penyumbatan) kedua saluran sperma sebelah kanan dan kiri, sehingga pada waktu ejakulasi cairan mani yang keluar tidak lagi mengandung sperma, sehingga tidak terjadi kehamilan. Tindakan ini lebih ringan dari sunat atau khitan, pada umumnya dilakukan sekitar 10-15 menit, dengan cara memotong dan mengikat saluran sperma (vas deferens) yang terdapat di dalam kantong buah zakar. ${ }^{19}$ Vas deferens (saluran mani) berfungsi sebagai tempat penyimpanan air mani sebelum disemprotkan. Vas deferens ada dua buah saluran, kiri dan kanan, berasal dari testis masuk ke dalam tali mani.

\footnotetext{
${ }^{17}$ Cik Hasan Bisri, Pilar-pilar Penelitian Hukum Islam dan Pranata Sosial (Jakarta: RajaGrafindo Persada, 2004), h. 230.

${ }^{18}$ Badan Kependudukan dan Keluarga Berencana, Informasi Pelayanan.., h. 1.

${ }^{19}$ Ibid., h. 11.

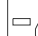

Jurnal Pemikiran Hukum Islam 
Muhyiddin

Menurut KH. Afifuddin Muhajir, vasektomi ialah tindakan memotong dan mengikat saluran spermatozoa dengan tujuan menghentikan aliran spermatozoa, sehingga air mani tidak mengandung spermatozoa pada saat ejakulasi tanpa mengurangi volume air mani. Pria/suami yang boleh menjadi peserta vasektomi adalah Pasangan Usia Subur (PUS) dengan syarat sebagai berikut: 1) Tidak ingin punya anak lagi; 2) Sukarela dan telah mendapat konseling tentang vasektomi; 3) Mendapat persetujuan dari istri/keluarga harmonis; 4) Jumlah anak sudah ideal, sehat jasmani dan rohani; 5) Umur istri sekurang-kurangnya 25 tahun; 6) Mengetahui prosedur vasektomi dan akibatnya; 7) Menandatangani formulir persetujuan (informed consent) ${ }^{20}$

\section{Vasektomi dalam Fatwa MUI}

Sebagaimana dijelaskan di muka, bahwa masalah vasektomi telah difatwakan oleh MUI sebanyak empat kali, yaitu fatwa tahun 1979, fatwa tahun 1983, fatwa tahun 2009, dan terakhir fatwa tahun 2012. Setiap fatwa tentang vasektomi dari 4 (empat) kali penetapan fatwa akan dikemukakan Diktum Fatwa atau Naș Fatwa, sehingga nantinya dapat dilihat dengan jelas maupun samar-samar bagaimana metode istinbāț-nya, atau alasan rasional mengapa hukum tersebut ditetapkan. Di antara alasan rasional itu, ada yang wujudnya 'illat hukum. Diktum fatwa-fatwa tersebut sebagai berikut:

\begin{tabular}{|c|c|}
\hline Tahun Fatwa & \multicolumn{1}{c|}{ Diktum Fatwa } \\
\hline 1979 & $\begin{array}{c}\text { Vasektomi hukumnya haram, karena: } \\
\text { 1) Pemandulan dilarang oleh agama. }\end{array}$ \\
& 2) Vasektomi/tubektomi adalah salah satu usaha pemandulan \\
& 3) Di Indonesia belum dapat dibuktikan bahwa vasektomi/ tubektomi \\
& dapat disambung kembali. \\
\hline 1983 & 1) $\begin{array}{c}\text { Melakukan vasektomi (usaha mengikat atau memotong saluran benih } \\
\text { pria (vas deferens), sehingga pria itu tidak dapat menghamilkan) dan } \\
\end{array}$ \\
& $\begin{array}{l}\text { tubektomi (usaha mengikat atau memotong kedua saluran telur, se- } \\
\text { hingga wanita itu pada umumnya tidak dapat hamil lagi) bertentangan } \\
\text { dengan Hukum Islam (haram), kecuali dalam keadaan sangat terpaksa } \\
\text { (darurat) seperti untuk menghindarkan penularan penyakit dari }\end{array}$ \\
\hline
\end{tabular}

${ }^{20}$ Ibid.

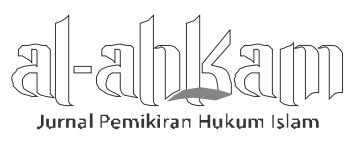




\begin{tabular}{|c|c|c|}
\hline & 2) & $\begin{array}{l}\text { ibu/bapak terhadap anak keturunannya yang bakal lahir atau ter- } \\
\text { ancamnya jiwa si janin apabila ia mengandung atau melahirkan lagi. } \\
\text { Menganjurkan kepada pemerintah untuk melarang pelaksanaan } \\
\text { vasektomi, tubectomi dan abortus bagi Umat Islam, serta meningkatkan } \\
\text { pengawasan terhadap penyalahgunaan alat-alat kontrasepsi yang ada } \\
\text { kemungkinan dipergunakan untuk perbuatan maksiat. }\end{array}$ \\
\hline 2009 & 1) & $\begin{array}{l}\text { sektomi hukumnya haram, karena: } \\
\text { Vasektomi sebagai alat kontrasepsi KB sekarang ini dilakukan dengan } \\
\text { memotong saluran sperma. Hal itu berakibat terjadinya kemandulan } \\
\text { tetap. } \\
\text { Upaya rekanalisasi (penyambungan kembali) tidak menjamin pulihnya } \\
\text { tingkat kesuburan kembali yang bersangkutan. }\end{array}$ \\
\hline 2012 & $\begin{array}{l}\text { 1) } \\
\text { 2) } \\
\text { 3) }\end{array}$ & $\begin{array}{l}\text { sektomi hukumnya haram, kecuali: } \\
\text { Untuk tujuan yang tidakmenyalahi syariat. } \\
\text { Tidak menimbulkan kemandulan permanen. } \\
\text { Ada jaminan dapat dilakukan rekanalisasi yang dapat mengembalikan } \\
\text { fungsi reproduksi seperti semula. } \\
\text { Tidak menimbulkan bahaya (madarat) bagi yang bersangkutan. } \\
\text { Tidak dimasukkan ke dalam program dan metode kontrasepsi } \\
\text { mantap21 }\end{array}$ \\
\hline
\end{tabular}

\section{Ulama yang Menolak Vasektomi Secara Mutlak, karena Menolak Program KB Secara Umum}

Para ahli fikih memandang masalah vasektomi terbagi menjadi tiga pandangan; yaitu pandangan yang mengharamkan secara mutlak, pandangan yang membolehkan secara mutlak, dan pandangan yang membolehkan apabila tidak berakibat pemandulan permanen. Diantara orang-orang yang menentang vasektomi, didasarkan pada penolakan terhadap praktik perencanaan keluarga yang dikenal sebagai program Keluarga Berencana (KB) Mereka mengutip pemikiran al-Qur'an untuk mendukung perlawanan mereka sebagai berikut: 1) Jumlah besar sangat dianjurkan dalam Islam, 2) Anak adalah hiasan kehidupan, 3) Melahirkan anak adalah tujuan perkawinan, 4) Kontrasepsi adalah wa'd atau pembunuhan, 5) Pe-

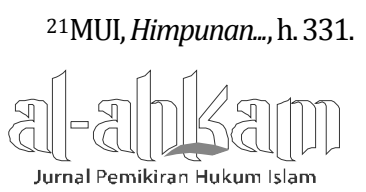


Muhyiddin

rencanaan keluarga bertentangan dengan kehendak Allah (qadar) dan meragukan kemampuan-Nya untuk memberikan rezeki.

Di samping itu, para penentang gerakan Keluarga Berencana mengklaim hal-hal berikut: 1) Gerakan itu adalah suatu konspirasi melawan Islam yang bertujuan untuk mengurangi jumlah penganutnya dan/atau mengurangi status mayoritas di beberapa negara. 2) Hal itu akan membawa serta kebebasan seksual, kemerosotan moral, sekularisasi, dan semua keburukan yang menurut klaim mereka, disebabkan olehnya di negara-negara Barat. 3) Yang dinamakan masalah kependudukan tidak berlaku pada dunia Islam, karena dunia Islam mempunyai sumber-sumber yang cukup untuk memelihara jumlah penduduk yang beberapa kali lebih besar. ${ }^{22}$

Di antara ulama yang termasuk kategori tersebut adalah Ibn Hazm, yang tinggal di Andalusia (Spanyol Islam) dan meninggal tahun 1063 M. Walaupun ia tidak berhasil meyakinkan ulama lain di zamannya, penolakannya dikutip dalam beberapa karya fikih Islam. Gagasan Ibn Hazm mewakili pendapat resmi mazhab Dhahiri yang berusia singkat itu, dan tercantum dalam bukunya al-muhallā.

Ibn Ḥazm menggunakan suatu kaidah mendasar dalam fikih Islam, yaitu bahwa dugaan primer dalam segala hal ialah diizinkan sampai hal itu dilarang oleh suatu naș. Tidak adanya nas yang melarang merupakan hujjah penting bagi orangorang yang menganggap al-'azl diizinkan. Oleh karena itu, Ibn Hazm menggunakan Hadis "Judamah" sebagai dasar argumentasinya. "Ia berhujah bahwa Hadis yang dilaporkan oleh Judamah mengukuhkan larangan al-'azl dan karena itu tentulah Hadis itu muncul pada waktu yang lebih kemudian, yang mempunyai efek untuk menghapus (me-nasakh) semua Hadis lainnya yang membolehkan al-'azl. Sementara ia tidak mengajukan bukti sejarah, ia menentang orang-orang yang mengklaim sebaiknya untuk memberikan bukti tentang waktu munculnya HadisHadis itu. Ia menganggap beberapa Hadis lainnya itu palsu. Ibn Hazm juga merujuk, walaupun secara singkat, makna ganda dalam Hadis Abū Sa'îd dan mengutip Ibn Sirīn dengan mengklaim bahwa Hadis itu lebih dekat kepada larangan. Secara paradoks, ia mengakui keabsahan Hadis-Hadis yang melaporkan diizinkannya al'azl oleh Jābir, Ibn 'Abbās, Sa'd ibn Abī Waqqāṣ, Zaid ibn Tsābit, dan Ibn Mas'ūd, tetapi melewatinya tanpa komentar. Ia juga membuat daftar nama-nama sahabat yang diklaimnya tidak menyukai atau tidak menyetujui al-'azl. Mereka itu meliputi

${ }^{22}$ 'Abd. al-Rahim 'Omran, Islam \& KB, (terj. dari Family Planning in the Legacy of Islam, London \& New York: Routledge) (Jakarta: Lentera Basritama, 1992), h. 246-247. 
'Alī ibn Abī Ṭālib, Ibn 'Umar, 'Umar, 'Utsmān ibn 'Affān, dan Ibn Mas'ūd, yang telah ia laporkan sebelumnya sebagai salah seorang yang menyetujui al-'azl. Tentu saja, ia keliru tentang 'Ali dan 'Umar, karena keduanya diketahui mengizinkan al-'azl."23

Ulama lain yang menolak adalah Abu Zahrah, guru besar syariat pada Fakultas Hukum Universitas Kairo dan penulis beberapa buku tentang ulama awal, menerbitkan suatu kritik pedas terhadap perencanaan keluarga dalam majalah Liw $^{\prime}$ al-Islām di tahun 1962.

Abū Zahrah mulai dengan merujuk kepada ayat-ayat al-Qur'an mengenai pembunuhan anak karena kemiskinan atau takut akan kemiskinan sebagaimana dalam QS. al-An'am: 151, dan al-Isra: 31. Shaykh Abū Zahrah menafsirkan "membunuh" sampai meliputi $w a^{\prime} d$ dan aborsi, karena yang terlibat ialah membunuh manusia (nyawa) yang telah diharamkan Allah. Ini klaimnya, "secara tidak langsung" meliputi pengendalian kelahiran, karena hal itu menyiratkan penyangkalan akan kemampuan Allah untuk memberikan rezeki. Apabila kaum Muslim benar-benar beriman kepada Allah maka mereka harus memasrahkan keturunan mereka dan dukungan yang mereka harapkan bagi keturunan mereka kepada Allah. Ia menyimpulkan bahwa naș-naș al-Qur'an memberi kesan larangan atas pengendalian kelahiran melalui sterilisasi atau sarana lain "karena takut kemiskinan."24

\section{Ulama yang Membolehkan Vasektomi Secara Mutlak}

Para penganut mazhab Imāmiyah membolehkan sterilisasi permanen, Shaykh M. Shamsuddin (dari kalangan Shī'ah Imāmiyah) mengungkapkan pembolehannya di Konferensi Rabat sebagai berikut:

"Ketika menguji sumber-sumber hukum kami tentang subjek itu, kami mendapatkan bahwa tidak ada sesuatu yang mencegah si suami dan si istri untuk menjalani operasi (untuk sterilisasi) semacam itu, karena pemeliharaan kemampuan untuk berkembang biak bukanlah kewajiban yang dibebankan oleh Hukum Islam, dan bukan suatu hak perkawinan. Karena itu, secara hukum diizinkan untuk menjalani operasi pembedahan (atau lainnya) untuk mensterilkan lelaki atau perempuan, baik ada kemungkinan bagi keduanya untuk mendapatkan kembali keadaan yang normal di masa depan ataupun tidak." 25

\footnotetext{
23Ibn Hazm, al-Muhallā (Kairo: al-Ṭibā'ah al-Munīriyyah, 1352), h. 70-71.

24'Abd. al-Rahim Omran, Islam \& KB, h. 229.

${ }^{25}$ Shaykh M. Shamsuddin, "Tahdidi” dalam Rabat Proceeding (IPPF, 1967).
}

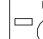

Jurnal Pemikiran Hukum Islam 
Muhyiddin

Ini pendapat pribadinya pada waktu itu (1971). Ia kemudian mengontak para pemimpin mazhab Imamiyah (terutama di Iran dan Lebanon), yang mayoritasnya mengizinkan sterilisasi (komunikasi pribadi di tahun 1974). ${ }^{26}$

\section{Ulama yang Membolehkan Vasektomi dengan Syarat}

Sebagian ulama berpendapat bahwa sterilisasi (vasektomi/tubektomi) dibolehkan, tetapi dengan syarat. Mufti Besar Mesir: Shaykh Jād al-Haq (Maret 1980), berpendapat bahwa sterilisasi tidak diizinkan apabila menyebabkan hilangnya kesuburan secara permanen, baik melalui pembedahan ataupun melalui obatobatan. Sterilisasi boleh digunakan apabila telah diketahui secara meyakinkan bahwa suatu penyakit menurun mungkin tersalur kepada anak atau menyebabkan sakit. Dalam hal demikian, sterilisasi menjadi wajib. Pembolehan ini didasarkan pada prinsip juristik yang mengizinkan kemadaratan untuk mengelakkan kemudaratan yang lebih besar. Ini benar, asal penyakit itu tidak tersembuhkan, dengan mempertimbangkan teknologi medis yang berkembang. 27 Pendapat serupa disampaikan Shaykh Shalțūt tentang tidak diizinkannya sterilisasi permanen, kecuali untuk alasan-alasan serius menyangkut penyakit keturunan atau yang mungkin menular. ${ }^{28}$ Dr. Madhkūr juga menentang dan mengutip juris mazhab Syafi'i, al-Bijurmī, yang mengatakan. "Dilarang menggunakan cara apapun yang menyebabkan hilangnya kapasitas alami untuk berkembang biak."29

Dalam konteks kelembagaan, Dewan tinggi penelitian Islam pada tahun 1965 menetapkan bahwa penggunaan sarana yang menjurus kepada kemandulan adalah terlarang. ${ }^{30}$ Larangan yang sama dikeluarkan oleh Dewan Fikih di Saudi Arabia. Sementara itu "Konferensi Rabat tentang Islam dan Keluarga Berencana" mengalami perselisihan pendapat serius ketika mendiskusikan tentang isu ini. Banyak peserta menentang, tetapi suatu kelompok minoritas mengungkapkan dukungan bagi sterilisasi, karena mereka tidak mendapatkan nas dalam al-Qur'an dan sunnah yang melarangnya. Para penentang mengangkat isu sterilisasi adalah suatu bentuk pengubahan ciptaan Allah. Namun, Shaykh Bahshatī dan Shaykh

\footnotetext{
26‘Abd. al-Rahim Omran, Islam \& KB, h. 229.

27Jād al-Haqq, “Ra'y al-Dīn fí Tanzīm al-Usrah”, dalam majalah al-Tasāwur fí 'l-Islām, No. 21, 1980

28Shaykh Mahmūd Shalțut, Fatāwa, (Kairo: al-Azhar Press, 1959)

${ }^{29}$ Madhkūr, Naẓrat al-Islām ilā Tanzīm al-Nasl (Kairo: Dār an-Nahḍah al-'Arabiyyah, 1965), h. 9495 dan Rabat Proceedings, al-Islām wa Tanżim al-Usrah (IPPF, 1967), h. 286-311.

${ }^{30}$ Academy (or High Council) of Islamic Research, Resolutions, 1965.
} 
Muhammad Shamsuddīn membela sterilisasi, sebagaimana dokter yang hadir. Pada dokter khawatir bahwa sterilisasi dikacaukan dengan pengebirian dalam pikiran para ulama yang bukan dokter itu. ${ }^{31}$

Beberapa ulama memasukkan pembahasan tentang sterilisasi dalam konteks perbandingan secara umum terhadap praktek kontrasepsi sementara, seperti al'azl. Mereka menyatakan bahwa tidak ada penentangan terhadap sterilisasi sementara, yang sama dengan al-azl dan kontrasepsi lain yang digunakan untuk jangka waktu lama, asal sterilisasi itu dilakukan secara sukarela tanpa paksaan dari siapapun. Demikian juga Shaykh Sayyid Sābiq memberikan suatu pernyataan bahwa sterilisasi dapat diizinkan oleh orang-orang yang mengizinkan al-'azl.32

Shaykh Aḥmad Ibrāhim, seorang ulama terkemuka pada paruh pertama abad kedua puluh, salah seorang yang pendapatnya dihormati sepenuhnya oleh rekan sezamannya. Ia meneliti masalah sterilisasi sebelum gerakan Keluarga Berencana masuk ke Timur Tengah, dan sebelum sterilisasi menjadi metode populer di beberapa negara Muslim. Dalam pengantarnya yang terkenal pada disertasi alSa'îd Muștafāa as-Sa'îd (1936), ia menyatakan bahwa: "tidak dilarang bagi seseorang untuk menggunakan sarana apa saja yang ada padanya untuk menghancurkan sperma, atau mencegahnya melewati saluran rahim wanita, atau membuatnya menjadi tidak efektif. Tidak perlu dikatakan lagi bahwa wanita itu boleh menggunakan atau memanfaatkan apa saja yang akan menjadikannya tidak subur untuk mengandung. Hal semacam itu tidak haram.

\section{Latar Belakang Lahirnya Fatwa Vasektomi 2012}

Proses dan latar belakang lahirnya fatwa Vasektomi 2012 tercermin dari naskah fatwa itu sendiri secara utuh. Karenanya perlu mencermati hal-hal sebagai berikut: Pertama, MUI dalam menetapkan fatwa vasektomi tahun 2012 sebagaimana diktum fatwa yang sudah dikemukakan di depan, di dalamnya membolehkan vasektomi dengan lima syarat, dan ditambah juga dengan menyampaikan empat rekomendasi kepada pemerintah. Kedua, Fatwa tersebut sejalan dengan pendapat ulama kontemporer sebagaimana tersebut di atas seperti, Mufti Besar Mesir: Shaykh Jadil Haq (Maret 1980), Shaykh Shaltut, Madhkur, Dewan Tinggi Penelitian 'Academy of Islamic Research'.

\footnotetext{
31"Abortion and Sterilization" dalam Rabat Proceedings, jilid 2, h. 279.

32Shaykh Sayyid Sābiq, Fiqh as-Sunnah, Jilid 7, Kuwait: Dār al-Bayān, 1968), h. 132-135.
}

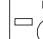

Jurnal Pemikiran Hukum Islam 
Muhyiddin

Membaca diktum fatwa yang menyertakan lima syarat ditambah empat butir rekomendasi kepada pemerintah, maka ada kesan pihak MUI atau sebagian dari mereka merasa agak keberatan dalam menetapkan kebolehan vasektomi. Atau paling tidak mereka ragu pada tahap implementasinya nanti, terutama penerapan syarat yang ditentukan. Oleh karena itu, bisa dipahami kalau pelaksanaan fatwa tersebut menuntut terbuktinya/terwujudnya syarat yang lima, lebih utama lagi syarat ketiga, yaitu "jaminan dapat dilakukan rekanalisasi yang dapat mengembalikan fungsi reproduksi" dan syarat kelima yaitu "tidak dimasukkan dalam program dan metode kontrasepsi mantap" yang didukung oleh rekomendasi pertama yaitu "agar pemerintah tidak memasukkan vasektomi sebagai program KB terbuka, umum dan massal". 33 Vasektomi dimungkinkan hanya sebagai program KB bagi orang-orang tertentu yang memenuhi persyaratan. Jadi, pihak MUI dengan fatwa tersebut mengharapkan agar ada kepastian bahwa lima syarat, terutama syarat ketiga dan kelima harus benar-benar terwujud meyakinkan; "tahaqquq wujūd almashrūt" dan benar-benar menjadi komitmen pemerintah, dalam hal ini Kementerian Kesehatan dan BKKBN.

Bisa jadi, di kalangan sebagian ulama, di balik penerimaannya terhadap adanya 'illat hukum baru berupa keberhasilan rekanalisasi yang didukung oleh fakta keberhasilan rekanalisasi Surabaya tahun 1999 dan pernyataan dokter ahli urologi Indonesia (IAUI) 12 Juni 2012, masih menyimpan keraguan psikis/ perasaan. Apakah keberhasilan rekanalisasi di Indonesia yang baru terbukti satu-dua ini bisa digeneralisasi menjadi 'illat hukum? Padahal bagi pihak yang menganggap standar hukum yang didasarkan pada 'illat itu harus "țahaqquq al-illat", maka kondisi seperti itu menjadi kurang meyakinkan. Keraguan itu bisa dimaklumi karena mungkin terpicu oleh mindset mereka yang sudah terbentuk oleh tiga kali fatwa vasektomi (1979-1983-2009) sebelumnya yang memfatwakan haram vasektomi. Sehingga dalam benaknya tertanam bahwa hukum asal vasektomi adalah haram, yang haram itu bisa mendapat rukhșah (dispensasi) menjadi mubah apabila keadaan darurat atau ada hajat mendesak. Bagi kalangan ulama tradisional, penerimaan terhadap perubahan hukum itu butuh proses panjang, butuh waktu yang cukup dan butuh adaptasi.

Jika benar ada keraguan, maka keraguan itu bisa dimaklumi juga karena inisiatif lahirnya fatwa vasektomi tahun 2012, bukan dari pihak MUI sendiri tapi lebih me-

\footnotetext{
33Majelis Ulama Indonesia, Keputusan Ijtima' Ulama Komisi Fatwa se-Indonesia IV (Jakarta: Majelis Ulama Indonesia, 2012), h. 132.
}

84 
rupakan permintaan pemerintah. Permintaan tersebut dilihat dari surat resmi Kementerian Kesehatan Republik Indonesia No. TU.05.02/V/ 1016/2012, tanggal 11 Juni 2012, perihal permohonan peninjauan fatwa vasektomi yang ditandatangani oleh Sekjen Kementerian Kesehatan RI, Ratna Rosita.

\section{Tanggapan Ulama terhadap Fatwa Vasektomi 2012}

Adapun tanggapan ulama bisa dipetakan sedikitnya menjadi dua kategori, yaitu tanggapan yang setuju dengan catatan atau syarat, (selain syarat yang telah ditentukan dalam forum), dan tanggapan yang tidak setuju atau cenderung tidak setuju terhadap fatwa tersebut. Masing-masing disertai dengan alasan tidak ditemukan pendapatyang setuju secara mutlak.

Tanggapan ulama yang menyetujui dengan syarat adalah sebagai berikut: Pertama, pada dasarnya mereka bisa menyetujui fatwa MUI tahun 2012 tentang vasektomi asalkan persyaratan yang ditentukan dalam fatwa tersebut secara utuh dan ketat terpenuhi. Maksudnya adalah syarat yang jumlahnya lima yang terdapat dalam Diktum Fatwa tahun 2012 sebagaimana sudah dikemukakan. Terutama persyaratan yang ketiga, yaitu keberhasilan rekanalisasi, karena hal itu menjadi faktor dominan dan alasan hukum atau 'illat hukum sehingga vasektomi bisa dibolehkan. Berkaitan dengan penekanan pada syarat yang ketiga, responden menyatakan kesetujuannya pemakaian dalil kaidah ushul: "al-ḥukmu yadūru ma'a 'illatihi wujūdan wa 'adaman". Tetapi ada atau tidaknya perubahan 'illat harus betulbetul valid atau nyata; "muhaqqaqan”, bukan sekedar dugaan yang meragukan.

Kedua, mereka memandang perlunya syarat tambahan yang menguatkan, yaitu: 1) Dokter yang menjadi provider dalam operasi vasektomi disyaratkan dokter laki-laki, bukan dokter perempuan untuk menghindari persoalan karena menyangkut aurat inti atau aurat besar, sehingga terjauh dari fitnah. 2) Untuk memenuhi hukum mubah vasektomi diperlukan syarat tambahan yaitu motivasi calon akseptor vasektomi, bahwa motivasinya positif, tidak negatif. Berkaitan dengan ukuran motivasi ini, bisa jadi dalam proses konseling diharapkan menghasilkan semacam rekomendasi dari ulama atau psikolog Muslim yang dapat menggambarkan bahwa calon akseptor tersebut tidak mempunyai motif yang menyimpang dari syariat.

Ketiga, kecuali memberikan persyaratan tambahan, responden juga merekomendasikan agar dilakukan kajian tindak lanjut terhadap definisi mengubah asal ciptaan Allah; "taghyīr al-khalqillāh". Dengan demikian menjadi jelas dan ada jaminan 
bahwa upaya memotong dan mengikat saluran spermatozoa atau vas deferens dalam operasi vasektomi termasuk taghyïr yang hukumnya haram atau taghyïr kecil yang mudah dima'fu karena ada hajat, atau bahkan tidak tergolong taghyir, karena begitu sederhananya pelaksanaan operasi vasektomi. ${ }^{34}$

Respon yang setuju terhadap fatwa vasektomi tahun 2012 dengan pengetatan syarat yang ada (dalam praktek pelaksanaannya) dan penambahan syarat baru itu sesungguhnya mirip dengan sikap ulama di atas, yakni sikap ragu memahami informasi keberhasilan rekanalisasi, karena bukti keberhasilannya baru satu-dua bukti, dianggap belum signifikan untuk mejadi illat baru yang mengubah hukum awal. Sebagai rekomendasi, mereka meminta agar syarat ketiga: "rekanalisasi berhasil" benar-benar terwujud dan meyakinkan dengan bukti yang signifikan. Inilah yang dimaksud dengan pengetatan syarat yang sudah ada dalam diktum fatwa.

Ada dua tambahan syarat yang direkomendasi oleh responden, pertama, syarat dokter yang melakukan operasi vasektomi adalah dokter laki-laki. Hal itu dimaksudkan untuk menekan sekecil mungkin persoalan sampingan yang mungkin timbul karena operasi vasektomi menyangkut aurat inti atau aurat besar dan dilakukan dalam kondisi calon akseptor sehat dan bugar. Kedua, motivasi calon akseptor disyaratkan harus bermotif yang positif. Syarat tambahan ini sejalan dengan syarat pertama yang ada dalam diktum fatwa, yaitu "untuk tujuan yang tidak menyalahi syariat". Secara umum, para responden memberi tanggapan fatwa vasektomi 2012 sebagai bukan fatwa yang bersifat ibạhah murni atau bebas, tetapi lebih merupakan hukum rukhșah atau dispensasi dari hukum asal haram menjadi mubah dengan syarat, atau dalam keadaan tertentu.

Adapun tanggapan ulama yang cenderung tidak/kurang setuju terhadap fatwa vasektomi MUI tahun 2012 yang membolehkan (ibāḥah) pelaksanaan vasektomi adalah sebagai berikut:

1. Pada dasarnya masalah vasektomi itu tidak ada dalil yang langsung (eksplisit) mengharamkan dan tidak ada dalil yang menghalalkan. Karenanya hukum vasektomi termasuk wilayah masalah ijtihādiyyah; 'majūl al-ijtihād', yang terbuka kemungkinan terjadinya perbedaan pendapat; ikhtilāfal-arä'.

2. Meskipun vasektomi masuk wilayah ijtihad, tetapi ulama kalangan NU memegangi garis manhaj penetapan hukum versi Bahth al-Masāil menggunakan qawl ulama dalam kitab-kitab yang biasa dijadikan sebagai marājï. Jadi upaya

\footnotetext{
34Wawancara terbuka dengan Rupii Amri pada tanggal 21 Agustus 2013 dan wawancara dengan A. ArifBudiman pada tanggal 26 Agustus 2013.
} 
yang dilakukan berupa rasionalisasi teks qawl ulama. Sedangkan masalah vasektomi tidak bisa merujuk langsung kepada qawl ulama. Karena tidak ada qawl, maka yang bisa dilakukan adalah ilhāq terhadap qawl yang mirip atau serupa. Ilhāq itu seperti qiyās, hanya saja qiyās itu dilakukan penyamaan terhadap masalah yang diatur naș Qur'an atau Hadis, sedangkan ilhāq dilakukan penyamaan terhadap masalah yang sudah dihukumi oleh qawl ulama.

3. Bahwa di kalangan para fuqaha ada kecenderungan menghukumi mubah mengikuti program Keluarga Berencana sepanjang menggunakan kontrasepsi yang bersifat "tandìm al-nasl”, yaitu mengatur kelahiran seperti menjarangkan kelahiran. Tetapi, mereka menghukumi haram apabila metode yang dipilih dalam Keluarga Berencana tersebut bersifat "taḥdìd al-nasl", yaitu membatasi jumlah anak dengan menghentikan kehamilan. Akan tetapi, melihat kenyataan di lapangan, maka yang ditemukan selalu "tahdīd al-nasl”. Sedangkan vasektomi merupakan bentuk taḥdìd al-nasl yang permanen, meskipun secara teori ada rekanalisasi, karena yang melakukan rekanalisasi pasti sangat sedikit, dan yang berhasil dibuktikan baru satu, di Surabaya.

4. Memang benar, ada dalil-dalil umum yang memungkinkan dipakai sebagai dalil bagi kebolehan program Keluarga Berencana, tetapi dalil tentang perintah nikah untuk tanāsul atau menganjurkan mengawini wanita yang walūd (beranak), itu jauh lebih kuat dan lebih jelas. Oleh karena itu, fatwa MUI yang membolehkan vasektomi dengan menghentikan fungsi tanāsul cukup kontroversi.

5. Karena kontroversi, maka disadari adanya dalil yang bisa mendukung kebolehan vasektomi, di samping dalil yang bisa dipakai menolak vasektomi. Maka, responden memilih yang melarang vasektomi sesuai dengan kemantapan hati, agar pelaksanaan hukum sejalan dengan kesadaran nurani. Oleh karena itu, pelaksanaan hukum agama memerlukan integrasi antara fikih, 'aqidah, dan tasawuf. Dengan integrasi tersebut, orang yang mengikuti program Keluarga Berencana karena takut beranak banyak, menjadi sedikit terganggu rasa tawakkalnya kepada Allah SWT.35

Kecenderungan penolakan terhadap fatwa vasektomi dalam fatwa MUI tahun 2012 secara metodologis didasarkan pada adanya dua illat hukum yang menjadi pertimbangan utama, pertama: terjadi perbuatan taghyīr al-khalqillāh; mengubah asal ciptaan Allah berupa memotong saluran spermatozoa atau vas deferens. Pengubahan terhadap asal ciptaan Allah tersebut terutama melihat dampaknya men-

\footnotetext{
35Wawancara dengan KH. Ubaedillah Shodaqoh, Rois Syariah PWNU Jawa Tengah, tanggal 27 Agustus 2013.
}

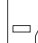

Jurnal Pemikiran Hukum Islam 
jadikan tidak dapat melaksanakan fungsi tanāsul atau reproduksi. Kedua, keberhasilan rekanalisasi untuk menyambung kembali saluran yang dipotong sehingga bisa mengembalikan fungsi reproduksi, belum sampai pada tingkat muhaqqaqah; nyata atau definitif, atau pasti secara hukum, melainkan baru pada tingkat mutawahhamah; dugaan/spekulasi berdasarkan teori kedokteran. Kalaupun ada bukti nyata, jumlahnya belum signifikan untuk dijadikan sebagai faktor perubahan 'illat yang dapat berakibat berubahnya hukum sejalan dengan kaidah ushul al-ḥukmu yadūru ma'a 'illatihi wujūdan wa 'adaman.

Sekiranya suatu ketika nanti, dengan kecanggihan ilmu pengetahuan dan teknologi, praktek rekanalisasi menjadi sesuatu yang mudah dilakukan, murah biayanya, sederhana caranya sebagaimana sederhananya operasi vasektomi, dan yang terpenting ada jaminan keberhasilan atau efektivitasnya dalam mengembalikan fungsi reproduksi, serta telah dibuktikan secara signifikan, maka hukum mubah vasektomi itu bisa diterima. Karenanya faktor yang menyebabkan keharaman berupa pemandulan permanen dan mengubah asal ciptaan Allah menjadi terkoreksi. Sampai sekarang, praktek operasi rekanalisasi belum seperti yang digambarkan di atas. Rekanalisasi masih merupakan operasi yang cukup rumit, biayanya relatif tinggi, hanya bisa dilakukan di rumah sakit-rumah sakit tertentu, dan oleh dokter ahli urologi tertentu. ${ }^{36}$

Kekurangsetujuan ini mencerminkan bahwa ikhtilaf ulama itu wajar terjadi dalam masalah-masalah yang bersifat ijtihādiyyah. Masalah vasektomi adalah masalah furū'iyah ijtihādiyah, maka berkonsekuensi munculnya perbedaan pandangan. Pangkal perbedaan ini bukan terletak pada penggunaan dalil atau kaidah yang dipakai dasar melainkan bertumpu pada penilaian terhadap dua hal yang menjadi poros hukum atau 'illat hukum, yakni pertama masalah adanya perilaku taghyīr alkhalqillāh (mengubah ciptaan Allah) berupa memotong saluran spermatozoa atau vas deferens. Dan kedua masalah jaminan keberhasilan rekanalisasi.

Menurut kelompok ini, bahwa pemotongan saluran spermatozoa itu termasuk kategori taghyir yang hukum dasarnya adalah haram. Keharamannya tidak bisa berubah menjadi haram, kecuali karena darurat atau hajat yang mendesak. Mereka meyakini pula bahwa dalam hal vasektomi di Indonesia, darurat atau hajat mendesak secara umum dianggap belum terwujud.

Dari uraian di atas, dapat disimpulkan pandangan ulama terhadap fatwa vasektomi 2012 dilihat dari ada atau tidaknya 'illat hukum baru yaitu keberhasilan

36Wawancara dengan Abu Hapsin, tanggal 29 Agustus 2013. 
rekanalisasi dengan kesimpulan sebagai berikut: pertama, MUI memandang illat hukum itu ada, karenannya lahirlah fatwa vasektomi tahun 2012 yang berbeda dengan tiga fatwa sebelumnya. Hanya saja ada kesan ragu pada tingkat pelaksanaannya, maka dilengkapilah fatwa tersebut dengan empat butir rekomendasi. Kedua, sebagian ulama cenderung menerima 'illat hukum baru berupa keberhasilan rekanalisasi, akan tetapi ada keraguan untuk bisa mengubah hukum karena bukti keberhasilan rekanalisasi baru satu-dua bukti. Ketiga, sebagian ulama lain memandang adanya bukti keberhasilan rekanalisasi yang baru satu-dua bukti tidak atau belum bisa dinilai sebagai 'illat baru yang mengubah hukum vasektomi.

Di samping itu, dalam menolak fatwa vasektomi diduga ada keharusan konsisten pada hukum vasektomi dan tubektomi hasil Baḥth al-Masā'il dalam Mu'tamar NU 1989 di Yogyakarta yang sampai saat ini belum dikaji ulang. Pandangan ini meyakini bahwa vasektomi itu pemandulan permanen.

\section{KB Pria (Vasektomi) di Jawa Tengah Pasca Fatwa MUI Tahun 2012}

Data tentang peserta Vasektomi di Jawa Tengah dalam tiga tahun terakhir adanya trend penurunan. Tahun 2011, peserta Vasektomi sebanyak 58.318 orang, tahun 2012 sebanyak 57.385 orang, dan tahun 2013 sebanyak 55.102 orang. Adapun data capaian pelaksanaan Vasektomi di Provinsi Jawa Tengah dalam tahun 2012 dan 2013 adalah sebagai berikut:

\begin{tabular}{lcc}
\hline \multicolumn{1}{c}{ Data } & Jumlah & Jumlah \\
& $\mathbf{2 0 1 2}$ & $\mathbf{2 0 1 3}$ \\
\hline $\begin{array}{l}\text { Capaian dalam satu tahun (Jan - Des) } \\
\text { PPM (Perkiraan Permintaan Masyarakat) }\end{array}$ & 3960 & \\
Realisasi & $2227(56 \%)$ & \\
& & \\
Capaian Semester I (Januari -Juni) & 3960 & 4186 \\
PPM & $1552(39,19 \%)$ & $832(19,88 \%)$ \\
Realisasi & & \\
Capaian Semester II (Jun - Des) & 3960 & \\
PPM & $679(17,4 \%)$ & \\
Realisasi & & \\
\hline
\end{tabular}


Muhyiddin

Berdasarkan data-data capaian di atas, dapat disimpulkan bahwa lahirnya fatwa MUI 1 Juli 2012, yang merevisi hukum vasektomi menjadi "boleh dengan syarat" belum berdampak pada peningkatan angka peserta vasektomi di Jawa Tengah, bahkan angkanya terlihat menurun. Sebelum lahirnya fatwa MUI tersebut, periode Januari-Juni 2012 peserta KB pria mencapai angka 1552 (seribu lima ratus lima puluh dua) peserta. Pada periode Juli-Desember 2012 peserta KB pria hanya mencapai 679 (enam ratus tujuh puluh sembilan) peserta. Kemudian pada periode terakhir Januari-Juni 2013 hanya mencapai angka 832 (delapan ratus tiga puluh dua) peserta.

Mengapa belum berdampak pada peningkatan peserta Vasektomi ? Beberapa kemungkinan analisisnya sebagai berikut: pertama, fatwa haram vasektomi yang sudah ditetapkan Majelis Ulama Indonesia sebanyak tiga kali (tahun 1979-19832009) dan ditambah dengan keputusan Bahth al-Masā'il NU tahun 1989 telanjur berpengaruh kepada masyarakat Muslim, sehingga meresap dalam kesadaran hukum mereka sebagai hukum yang diyakini. Perubahan hukum dengan fatwa baru belum atau tidak serta merta mengubah sikap yakin mereka. Kedua, fatwa kebolehan vasektomi, dalam fatwa tahun 2012 belum tersosialisasi secara efektif sampai ke akar rumput. Selama ini, di Jawa Tengah sosialisasi baru pada tingkat ulama kabupaten atau kota. Sosialisasi dari ulama ke masyarakat langsung belum dilakukan. Ketiga, fatwa haram vasektomi belum tentu menjadi faktor utama penghambat program KB pria. Keengganan kaum pria untuk aktif ber-KB dengan cara vasektomi bukan karena keharamannya, melainkan lebih disebabkan karena sikap yang tidak mau repot dalam soal pemenuhan kebutuhan seks dan pengaturan jumlah anak. Umumnya menganggap soal itu adalah urusan ibu-ibu. Sikap seperti itulah yang oleh Kabid KB-KR BKKBN Provinsi Jawa Tengah disebut faktor budaya. Ada yang bilang faktor budaya cukup dominan dibanding faktor hukum agama. ${ }^{37}$

\section{Kesimpulan}

Dari uraian di atas dapat disimpulkan sebagai berikut: pertama, MUI mengubah fatwa hukum vasektomi dari haram menjadi halal (atau mubah dengan syarat) karena telah menemukan 'illat baru berupa keberhasilan rekanalisasi, sehingga hukum menjadi berubah sesuai dengan 'illat tersebut. Sebagian ulama

\footnotetext{
37Wawancara dengan Erna Sulistiyowati, Kepala Bidang KB-KR, tanggal 18 Juli 2013, di Kantor BKKBN Jawa Tengah.

90

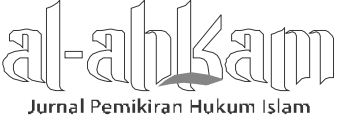


(Muhammadiyah) merespon fatwa vasektomi 2012 setuju dengan pengetatan dan penambahan syarat tertentu. Sebagian ulama lain (NU) meresponnya dengan kurang setuju terhadap fatwa vasektomi 2012, karena bukti keberhasilan rekanalisasi, yang baru satu-dua bukti dianggap belum meyakinkan (muhaqqaqah). Dua macam respon ini membuktikan bahwa masalah vasektomi merupakan masalah ijtihādiyyah yang memungkinkan lahirnya perbedaan pendapat.

Kedua, lahirnya fatwa vasektomi di bulan Juli 2012 yang membolehkan vasektomi dengan syarat, belum berdampak pada peningkatan jumlah kesertaan $\mathrm{KB}$ pria vasektomi di Jawa Tengah. Hal ini berarti bahwa fatwa haram vasektomi sebelum tahun 2012 tidak menjadi faktor utama rendahnya angka vasektomi. [a]

\section{DAFTAR PUSTAKA}

Badrān, Abū al-'Aynayn, Ușūl al-Fiqh al-Islāmī, Iskandariyah: Mu'assasah Shabāb alJāmi'ah, 1984.

Bisri, Cik Hasan, Pilar-pilar Penelitian Hukum Islam dan Pranata Sosial, Jakarta: RajaGrafindo Persada, 2004.

BKKBN, Informasi Pelayanan Kategori Mantap Pria (Vasektomi), Jakarta: BKKBN, 2011.

al-Ghazālī, Abū Ḥāmid Muhammad ibn Muhammad, al-Mustașfā min 'Ilm al-Ușūl, Jilid 2, t.t.p.: Dār al-Fikr, t.th.

al-Haq, Jād, "Ra'y al-Dīn fi Tanḍim al-Usrah", dalam Majalah al-Tașawwur fi 'l-Islām, No. 21, 1980.

Hazm, Ibn, al-Muhallā, Kairo: al-Ṭibā'ah al-Munīiyyah, 1352.

Jād al-Ḥaq, "Ra'y ad-Dīn fì Tanzīm al-Usrah", dalam Majalah al-Tașawwur fi 'l-Islām, No. 21,1980

Madhkūr, Nazrat al-Islām ilā Tanzīm al-Nasl, Kairo: Dār al-Nahḍah al-'Arabiyyah, 1965.

Mudzhar, M. Atho', Fatwa-fatwa MUI: Sebuah Studi tentang Pemikiran Hukum Islam di Indonesia Tahun 1975-1988, Jakarta: INIS, 1993.

Mudzhar, M. Atho', Pendekatan Studi Islam dalam Teori dan Praktek, Yogyakarta: Pustaka Pelajar, 2002.

MUI, Himpunan Fatwa MUI, Jakarta: Ditjen BIPH Depag RI, 2003.

MUI, Himpunan Fatwa MUI, Jakarta: Ditjen BIPH Depag RI, 2010.

MUI, Himpunan Fatwa MUI, Jakarta: Ditjen BIPH Depag RI, 2011.

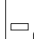

Jurnal Pemikiran Hukum Islam 
Muhyiddin

MUI, Keputusan Ijtima' Ulama Komisi Fatwa se-Indonesia III, Jakarta: MUI, 2009.

MUI, Keputusan Ijtima' Ulama Komisi Fatwa se-Indonesia IV, Jakarta: MUI, 2012.

'Omran, Abd. al-Rahim, Islam \& KB, (terj. dari Family Planning in the Legacy of Islam, London \& New York, Routledge), Jakarta: Lentera Basritama, 1992.

Rosjidi, Ajip, (ed.), Ensiklopedi Indonesia 2, Jakarta: Ichtiar Baru Van Hoeve, 1991.

Sābiq, Shaykh Sayyid, Fiqh al-Sunnah, Kuwait: Dār al-Bayān, 1968.

Shalțut, Shaykh Mahmūd, Fatwa, Kairo: al-Azhar Press, 1959.

Shamsuddin, Shaykh M., "Tahdidi” dalam Rabat Proceeding, Rabat: IPPF, 1967.

Shamsuddin, Shaykh M., "Abortion and Sterilization" dalam Rabat Proceeding, Rabat: IPPF, 1967.

Syarifuddin, Amir, Ushul Fiqh, Jakarta: Logos Wacana Ilmu, 1999.

Yahya, Mukhtar dan Fatchurrahman, Dasar-dasar Pembinaan Hukum Fikih Islam, Bandung: al-Ma'arif, 1986.

Yunus, H. Mahmud, Kamus Arab-Indonesia, Jakarta: Yayasan Penyelenggara Penterjemah/Pentafsir al-Qur'an, 1973.

92 || Volume 24, Nomor 1, April 2014 